\title{
Analisis Wacana Kritis Pada Media Massa Daring (Online) Bantennews.co.id Kolom Hukum Edisi Februari 2021
}

\author{
Asep Yana Yusyama, Ratna Khoirunnisa \\ Politeknik Negeri Jakarta \\ Correspondence email: asep.yana@mesin.pnj.ac.id, ratna.khoirunnisa@mesin.pnj.ac,id
}

\begin{abstract}
Abstrak: Berita dalam kolom media massa telah banyak merubah paradigma masyarakat sejak dahulu. Semakin berkembangnya zaman, media massa juga semakin progresif dan dinamis pemberitaannya. Saat ini ramai media berita berupa daring (online) yang memang proses pemberitaanya relatif cepat dibanding media massa konvensional, apalagi jika dikaji dari sudut pandang wacana kritis (critical discourse). Pertanyaan penelitian ini adalah "Bagaimanakah deskripsi analisis reprsentasi, relasi, dan identitas model Fairclough terhadap Analisis Wacana Kritis (AWK) kolom Hukum media massa daring bantennews.co.id edisi Februari 2021. Tujuan dari dilakukannya penelitian ini ialah untuk mendeskripsikan analisis representasi, relasi, dan identitas model Fairclough terhadap Analisis Wacana Kritis (AWK) kolom hukum harian daring bantennews.co.id edisi Februari 2021. Metode yang digunakan dalam penelitian ini adalah metode kualitatif, teknik pengumpulan data yang digunakan adalah teknik dokumentasi; adapun teknik analisis data yang digunakan adalah kajian isi. Sumber data penelitian ini adalah Analisis Wacana Kritis (AWK) kolom hukum media massa daring bantennews.co.id edisi Februari 2021. Berdasarkan hasil penelitian yang dilakukan, teks berita kolom hukum harian bantennews.co.id mengandung wacana suatu kndisi fenomena sosial yang terjadi di masyarakat kita semakin lama semakin beragam kasus kejahatan yang terjadi. Motifnyapun bebeda-beda, ada yang dilakukan oleh tersangka residivis, pengangguran, hingga Aparatur Sipil Negara (ASN). Korban yang tertindas dalam teks wacana ialah masyarakat biasa, perempuan, hingga orang yang secara psikologis merasa tidak diterima di tengah-tengah masyarakat.
\end{abstract}

Kata kunci: Wacana, kritis, bentennews.co.id

\begin{abstract}
News in the mass media column has changed the paradigm of society since long time ago. As the times progress, the mass media are also increasingly progressive and dynamic in reporting. Currently, there are many news media in the form of online which is indeed a relatively fast reporting process compared to conventional mass media, especially when examined from a critical discourse point of view. The research question is "What is the description of the Fairclough model's analysis of representation, relation, and identity to the Critical Discourse Analysis (AWK) of the online mass media online mass media bantennews.co.id edition, February 2021. The purpose of this research is to describe the analysis of representations, relations, and the identity of the Fairclough model of Critical Discourse Analysis (AWK) in the online daily law column of bantennews.co.id, February edition, 2021. The method used in this study is a qualitative method, the data collection technique used is documentation technique; As for the data analysis technique used was content review. The data source of this research is Critical Discourse Analysis (AWK) in the online mass media law column bantennews.co.id February edition, 2021. Based on the results of the research, the news text of the bantennews.co.id daily law column contains a discourse on a condition of social phenomena that occurs in Our society is getting more and more various cases of crimes that occur. The motives are different, some have been carried out by suspects from recidivists, unemployed, to the State Civil Service (ASN). Victims who are oppressed in the text of discourse are ordinary people, women, to people who psychologically feel unacceptable in the midst of society.
\end{abstract}

Keyword: Discourse, critical, bentennews.co.id

\section{PENDAHULUAN}

Kebutuhan manusia akan informasi saat ini semakin tinggi. Media untuk menggali informasi pun saat ini semakin canggih. Hadirnya model pemberitaan daring (online) menjadi sumber media yang dicari pembaca selain media pemberitaan konvensional. Selain beritanya cepat, update, jumlah teks beritanya juga tidak terlalu banyak, sehingga sesuai dengan kebutuhan pembaca yang malas membaca teks terlalu panjang. Berita/informasi yang dikonsumsi pembaca beragam, mulai dari politik, sosial, budaya, agama, hukum, ekonomi, pendidikan, baik yang bersifat local, nasional maupun internasional. Kekuatan media masa sekarang ini membuktikan bahwa maju atau tidaknya suatu pemikiran masyarakat tergantung pada media, dan media mampu mengubah persepsi masyarakat tentang suatu permasalahan. Media massa semakin lama semakin menjamur, khususnya media pemberitaan daring. Dianggap praktis dan cepat, media daring bisa diakses oleh semua kalangan dan tak terbatas ruang. Media digital yang semakin baik secara perlahan membangun kesadaran para pengguna dunia maia untuk membuka pemberitaan yang seringkali muncul pada laman social media.

Di Banten, media massa daring semakin menjamur, salah satunya bantennews.co.id. bantennews.co.id yang didirikan oleh Wahyu Arya sebagai inisiator. Sejak kemunculannya media daring bantennews.co.id mampu menari minat para pembaca khususnya di Banten karena konten pemberitaannya yang cukup menarik dan kompleks. Meida daring tersebut selalu menyajikan berita semenarik dan seberagam mungkin guna memberi informasi update seputar 
peristiwa-peristiwa di Banten, nasional maupun berita internasional. Terkadang yang menarik adalah masing-masing media cetak memiliki afiliasi tersendiri. Sebagai contoh salah satu media yang selalu memberikan berita yang Pro pemerintah, artinya beritanya selalu menyajikan tentang keberpihakan pada pemerintah, akan tetapi ada juga media yang berani memberitakan pemerintah dengan segala bentuk ketidakberesannya/kontranya. Yang jelas hal itu tetap menjadi warna tersendiri, dan masyarakat kembali yang menjadi penilai utamanya.

Tingkat kecerdasan masyarakat salah satunya dapat didorong dari sajian pemberitaan-pemberitaan media massa. Hal itu mengindikasikan bahwa betapa berpengaruhnya peran media massa terhadap suatu kekuatan tingkat kritis seorang pembaca, karena pada dasarnya benar istilah bahwa jika ingin menguasai masyarakat maka harus kuasai media.Sebuah pemberitaan yang tersaji guna menjadi konsumsi masyarakat luas salah satunya tergantung pada proses penyajian bahasanya. Bahasa mampu memikat ketertarikan pembaca untuk memahami informasi apa yang ingin disampaikan dalam suatu kasus/peristiwa. Bahasa mampu menularkan emosi pro-kontra pembaca tergantung tingkat intelektual, kekritisan pemikiran pembaca yang cenderung berbeda.

Penelitian mengenai bahasa tentu sudah banyak dilakukan, karena bahasa merupakan objek vital yang bersentuhan langsung dengan manusia, maka dari itu pengkajian atau penelitiannya akan terus berlangsung selama manusia masih menggunakan bahasadalam segala aspek kegiatan. Begitu banyak metode mengenai teknik pengkajian bahasa, yakni salah satunya Analisis Wacana Kritis (AWK). Menurut Purnomo (2006:3), "Analisis wacana kritis (AWK) merupakan penerapan wacana dengan perspektif interdisipliner." Apabila analisis wacana hanya difokuskan pada penggunaan bahasa alamiah dengan analisis semata-mata bersifat linguistis, analisis wacana kritis juga berusaha menjelaskan penggunaan bahasa dikaitkan dengan perspektif disiplin lain, seperti politik, gender, dan faktor sosiologis lain. Selain itu, Fairclough dan Wodak (dalam Eriyanto, 2009:07) menyatakan, "Analisis wacana kritis melihat wacana pemakaian bahasa dalam tuturan dan tulisan sebagai bentuk dari praktik sosial." Dalam bingkai AWK, wacana dengan beragam bentuknya merupakan aplikasi dari praktik sosial.

Bahasa menjadi objek penelitian analisis wacana kritis tentu memilki dasar dan tujuan tersendiri. Dasar dan tujuan dari analisis wacana kritis adalah menjelaskan konteks linguistik dalam hal kewacanaan fenomena sosial masyarakat dan kultural dan proses modernitas terkini (Jorgensen dan Phillips, 2007:116). Dalam hal ini, AWK memiliki tujuan untuk mempelajari bagaimana kekuasaan bisa dipersalahgunakan yang dapat diproduksi melalui teks. Kekuatan dari analisis wacana adalah kemampuannya untuk melihat dan menganalisis serta membongkar praktik suatu ideologi/pemikiran subjek pemberitaan dalam wacana. Kita bisa melihat bagaimana bahasa mampu digunakan oleh individu / kelompok tertntu sebagai alat guna mengekspresikan maksud dari tujuannya dalam sebuah teks. Bahasa dapat dianalisis bukan hanya menggambarkan aspek kebahasaan saja, namun juga dapat dihubungkan dengan konteks, artinya konteks di sini ialah konteks yang bertujuan bahasa digunakan sebagai alat/media guna mencapai tujuan dan praktik tertentu, terutama praktik kekuasaan.

\section{Landasan Teori}

Menurut Lubis (1991:20), menyatakan bahwa "Wacana adalah kesatuan bahasa yang lengkap." Pendapat lain diutarakan Stubss (dalam Tarigan, 1993:10) wacana merupakan organisasi bahasa di atas kalimat atau di atas klausa; dengan perkataan lain unit-unit linguistik yang lebih besar daripada kalimat atau klausa, seperti percakapanpercakapan atau teks-teks tertulis.

Menurut Darma (2009:10) wacana merupakan tataran bahasa yang terbesar, tertinggi, dan terlengkap. Wacana dikatakan terlengkap karena wacana mencakup tataran di bawahnya, yakni fonologi, morfologi, sintaksis, semantik, dan ditunjang oleh unsur lainnya, yaitu situasi pemakaian dalam masyarakat. Wacana terbentukdari paragraf-paragraf, sedangkan paragraf dibentuk oleh kalimat-kalimat, kalimat terdiri atas kata, frasa, dan klausa yang membentuk paragraf itu haruslah merangkai kalimat satu dengan kalimat berikutnya dan harus berkaitan sehingga membentuk satu kesatuan yang utuh dan membentuk suatu gagasan.

Menurut Yuwono (2009:92) wacana adalah kesatuan makna (semantis) antar bagian di dalam suatau bangun bahasa. Dengan kesatuan makna, wacana dilihat sebagai bangun bahasa yang utuh karena setiap bagian dalam wacana itu berhubungan secara padu. Di samping itu, wacana juga terikat pada konteks. Sebagai kesatuan yang abstrak, wacana dibedakan dari teks, tulisan bacaan, tuturan, atau inskripsi, yang mengacu pada makna yang sama 'wujud konkret yang terlihat, terbaca, atau terdengar'.

Menurut Darma (2009:49) Analisis wacana kritis (AWK) adalah sebuah upaya atau proses (penguraian) untuk memberi penjelasan dari sebuah teks (realitas sosial) yang akan atau sedang dikajai oleh seseorang atau kelompok dominan yang kecenderungannya mempunyai tujuan tertentu untuk memperoleh apa yang diinginkan. Artinya, dalam sebuah kontekswacana harusterdapatsuatu kepentinganpenutur/penuliswacana. Oleh karena itu, analisis wacanayang terbentuk nantinya secarasadartelah dipengaruhi oleh si penutur/penulis dari berbgai pandangan. Selain itu dalam wacanajuga terdapat sebuahmakna yang menjadi maksud serta kepentingan sipenulis sebagai media penyampai tujuannya. 
Wacana adalah sebuah proses pengembangan dari berbagaikomunikasi yang menggunakan simbol-simbol yang berkaitan dengan interpretasi dan peristiwa-peristiwa di dalam sistem kemasyarakatan yang kompleks. Melalaui pendekatan wacana pesan-pesan komunikasi, entah yang berbentuk kata-kata, tulisan, gambar, maupun media lainnya. Keberadaan wacanactersebut ditentukan olehpihak, orang, maupun kelompok yang menggunakannya, pokoknya yang berkaitan dengan peristiwa yang berkenaan dengannya yang melibat kansituasi masyarakat luas yang menjadi konsumen wacana.Bentuk dari wacana itu sendiri dapat berupa nilai-nilai, ideologi, emosi, kepentingan dan lain-lain.

Analisis wacana yang dimaksud dalam tulisan ini adalah upaya pengungkapan interpretasi tersembunyi dari subjek (penutur/penulis) yang mengungkapkan suatu statement tentang suatu permasalahan. Pengungkapan tersebut dilakukan dengan cara penulis menempatkan diri pada posisi penutur/nara sumber langsung sehingga bentuk distribusi dan produksi ideologi yang dituliskan dalam wacana dapat diketahui. Artinya, wacana dapat dilihat dari bentuk hubungan kekuasaan terutama dalam pembentukan subjek dan berbagai tindakan representasi.

Menurut ahli wacana kritis Fairclough dan Wodak (dalam Eriyanto, 2008:7), analisis wacana kritis melihat wacana dan pemkaian bahasa dalam tuturan dan tulisan sebagai bentuk dari praktik sosial. Menggambarkan wacana sebagai sebagai praktik sosial menyebabakan sebuah hubungan dialektis di antara peristiwa diskursif tertentu dan situasi, institusi, dan struktur sosial yang membentuknya. Praktik wacana bisa jadi menampilkan efek ideologi: wacana memproduksi dan mereproduksi hubungan kekuasaan yang tiadak imbang antara kelas sosial, laki-laki dan wanita, kelompok mayoritas dan minoritas melalui mana perbedaan itu direpresentasikan dalam posisi yang ditampilkan.

Hikam (dalam Eriyanto, 2008:9) berpandangan bahwa analisis wacana kritis dipkai untuk membongkar kekuasaan yang ada dalam setiap proses bahasa: batasan-batasan apa yang diperkenankan menjadi wacana, perspektif yang meski dipakai, topik apa yang dibicarakan. Artinya, dengan hadirnya pendapat semacam ini, wacana mampu memandang bahasa selalu terlibat dalam hubungan suatu kekuasaan, terutama pembentukan subjek, dan berbagi tindakan representasi yang terdapat pada khalayak luas.

Maka, berdasarkan pendapat para ahli di atas dapat disimpulkan bahwa analisis wacana kritis (AWK) adalah suatu usaha pengungkapan maksud tertentu ataupun ideologi dari pemakaian bahasa atau wacana yang ditulis atau dituturkan oleh narasumber tentang suatu permasalahan. Kata 'maksud' tersebut dapat dilihat dari teks, praktik wacana dan praktik sosial budaya pada sebuah wacana.

\section{METODE}

Penelitian mengenai Analisis Wacana Kritis (AWK) ini menggunakan metode kualitatif dalam melakukan penelitian wacana kritis pada harian bantennews.co.id. Menurut Creswell (dalam Satori: 2010: 24) metode kualitatif adalah suatu proses Inquiri tentang pemahaman berdasar pada tradisi-tradisi metodologis terpisah; jelas meneliti suatu masalah sosial atau manusia. Metode kualitatif bersifat kompleksitas, artinya menekankan pada gambaran holistik, meneliti kata-kata, laporan-laporan merinci pandangan-pandangan dari penutur asli, dan melakukan studi di suatu pengaturan yang alami. Metode ini berkaitan dengan pengkajian pada analisis representasi, relasi, identitas dan intertekstualitas wacana. Dalam melakukan penelitian ini, beberapa tahap akan dilakukan guna mengumpulkan data guna terwujudnya penelitian ini.

1. Studi pustaka yang bertujuan untuk memperoleh berbagai informasi teori yang berhubungan dengan masalah yang diteliti dari berbagai sumber kepustakaan terutama tentang wacana kritis.

2. Teknik dokumentasi. Menurut Moleong (2006:216-217) dokumentasi ialah setiap bahan tertulis ataupun rekaman, yang tidak dipersiapkan karena adanya permintaan seorang peneliti. Dalam penelitian ini, data-data yang diambil sebagai objek penelitian ialah tulisan-tulisan berupa teks berita kolom hukum harian Bantennews.co.id edisi Februari 2021.

Kemudian dalam melakukan penelitan ini, peneliti melakukan pembatasan pada kurun waktu dan jumlah tertentu, artinya tidak penuh dalam satu bulan pembebritaan dibahas, dipilih berdasarkan kemenarikannya dan uptudatenya berita tersebut agar dapat memfokuskan penelitian ini. Keseluruhan data tersebut akan dianalisis dengan menggunakan metode analisis wacana kritis Norman Fairclough. Proses teknik analisis data ini, teks kolom hukum harian bantennews.co.id edisi Februari 2021 yang akan dibahas satu persatu dalam kurun waktu yang telah ditentukan, berdasarkan metode analisis wacana kritis Norman Fairlough, proses analisis data yang akan dilakukan dalam penelitian ini mencakup analisis-analisis tertentu yang mengacu pada teori teks Fairlough.

Dalam penelitian ini, analisis isi digunakan untuk mendeskripsikan secara objektif, sistematis, dan apa adanya mengenai suatu data sehingga dapat diambil simpulannya berdasarkan analisis yang telah dilakukan. Langkah-langkah analisis data yang akan ditempuh dalam penelitian ini adalah sebagai berikut.

1. membaca sumber data berupa berita hukum dan kriminal harian Bantennews.co.id edisi Februari 2021

2. mengidentifikasi data; 
3. membuat penandaan data;

4. menganalisis unsur-unsur tekstual dan praktik wacana berupa unit-unit bahasa yang terdapat dalam berita hukum harian bantennews.co.id edisi Februari 2021

5. menyimpulkan hasil analisis.

Dalam kolom teks berita hukum dan kriminal harian Bantennews.co.id ini akan didasarkan pada tiga unsur, yaitu representasi, relasi dan identitas. Adapun penjelasannya ialah sebagai berikut:

1. Representasi merupakan tampilan dan gambaran peristiwa, orang, kelompok, situasi, dan keadaan yang terdapat dalam teks. Artinya, representasi pada dasarnya ingin melihat bagaimana seseorang, kelompok, tindakan, kegiatan ditampilkan dalam sebuah teks. Representasi dalam pengertian Fairclough dilihat dari dua aspek, yakni bagaimana seseorang, kelompok dan gagasan ditampilkan dalam sebuah anak kalimat dan gabungan atau rangkaian antaranak kalimat.

2. Relasi merupakan kaitan atau hubungan antara wartawan, khalayak, dan partisipan berita yang terdapat digambarkan dalam sebuah teks.

3. Identitas, yakni suatu perwujudan identitas wartawan, khalayak, dan partisipan berita yang juga terdapat di dalam teks. Aspek identitas ini terutama dilihat oleh Fairclough dengan melihat bagaimana identitas wartawan sendiri sebagai objek yang ditampilkan dan dikonstruksi dalam teks pemberitaan.

Penelitian yang dilakukan ini tentu memerlukan data yang berasal dari sumber data penelitian. Menurut Arikunto (2006:129) sumber data penelitian adalah subjek dari mana data diperoleh. Dalam penelitian ini,sumber data diperoleh dari media massa daring bantennews.co.id edisi Februari 2021, sedangkan data-data dalam penelitian ini adalah kata-kata dan kalimat-kalimat yang mengandung aspek ideologi pada kolom hukum harian bantennews.co.id edisi Februari 2021.

\section{HASIL DAN PEMBAHASAN}

Sumber data penelitian ini adalah kolom hukum media massa daring edisi Februari 2021, yang terdiri atas 4 berita. Sumber data/judul yang dipilih ialah yang menarik untuk dikaji atau dikritisi sesuai dengan teor Norman Fairlough, yaitu (1) Pelaku Pembunuhan Sadis Wanita Penjual Sayur di Cikande Ditangkap Polisi, (2) Polres Pandeglang Bongkar Kuburan Korban Miras Oplosan, (3) Oknum ASN Staf Kecamatan Pabuaran Serang Terlibat Mafia Tanah. Adapun aspek yang dianalisis dalam penelitian ini meliputi dua aspek, yakni: (1) Aspek Tekstual berupa telaah pada aspek representasi (frasa, klausa, kalimat, dan subjek kalimat), relasi, dan identitas dan (2) Telaah PraktikKewacanaan yang mengacu pada aspek produksi teks.

Dalam analisis ini, penulis hanya meneliti delapan berita saja dari edisi satu bulan. Mengingat keterbatasan media, kemampuan analisis, waktu dan lainnya. Kedelapan berita tersebut terdapat dua berita politik, enam berita hukum dan kriminal dengan objek berita sekitar daerah Banten, kemudian selebihnya berita nasional.

Untuk kepentingan analisis, data penelitian dituliskan dengan kode yang bertujuan untuk mempermudah peneliti dalam menganalisis data yang diinventarisasi.Tabel data yang dilakukan adalah sebagai berikut.

Judul dan halaman berita yang dijadikan sumber data.

\begin{tabular}{|c|c|c|c|c|}
\hline No & Data & Hri/Tanggal & Halaman/kolom & Judul \\
\hline 1 & Data 1 & Kamis, 12/02/2021 & Hukum & $\begin{array}{l}\text { Pelaku Pembunuhan Sadis Wanita Penjual Sayur di Cikande } \\
\text { Ditangkap Polisi }\end{array}$ \\
\hline 2 & Data 2 & Kamis, 18/02/2021 & Hukum & Polres Pandeglang Bongkar Kuburan Korban Miras Oplosan \\
\hline 3 & Data 3 & Jumat, 19/02/2021 & Hukum & $\begin{array}{l}\text { Oknum ASN Staf Kecamatan Pabuaran Serang Terlibat Mafia } \\
\text { Tanah }\end{array}$ \\
\hline
\end{tabular}

\section{Data 1}

\section{Pelaku Pembunuhan Sadis Wanita Penjual Sayur di Cikande Ditangkap Polisi}

SERANG - Tim Reserse Mobile (Resmob) Polres Serang akhirnya menangkap pelaku pembunuhan sadis, MA (43) ibu penjual sayuran di Jalan Kandang Sapi, Kampung Kayu Areng, Desa Parigi, Kecamatan Cikande, Kabupaten Serang, Kamis (11/2/2021). (Paragraf 1 ...)

Terbakar berahi, pelaku kemudian mencekik korban hingga menghembuskan napas terakhir. Jenazah korban akhirnya diperkosa oleh pelaku. (Paragraf $6 . .$. )

"Tersangka terpaksa dilakukan tindakan tegas dan terukur karena mencoba melawan dan tidak mengindahkan tembakan peringatan," tegas Mariyono didampingi Kasatreskrim AKP David Adhi Kusuma. (Paragraf 11...) 


\section{Deskripsi \\ Aspek Tekstual \\ Representasi}

Representasi dalam teks menurut Fairchlough menjelaskan tentang bagaimana peristiwa, orang, kelompok, situasi, keadaan, atau apapun ditampilkan dan digambarkan dalam teks. Pada paragraf pertama berita tersebut terdapat leksem "sadis". Kata sadis biasa dipakai dalam makna kejam. Menurut KBBI sadis memiliki arti tidak mengenal belas kasihan; kejam; buas; ganas; kasar. Namun di sini leksem 'sadis' sengaja dipakai sebagai judul untuk megindikasikan eksistensi sebuah kondisi bahwa manusia jika akalnya sudah hilang maka ia bisa bertindak lebih kejam daripada binatang. Pada paragraf enam terdapat leksem "berahi". Jika merujuk pada arti KBBI bahwa 'berahi' memilki arti perasaan cinta kasih antara dua orang yang berlainan jenis kelamin. dalam konteks di sini redaktur memilih kata 'berahi' dibandingkan 'hasrat' karena ingin merepresentasikan bahwa berahi identik dengan gejala ketertarikan dengan lawan jenis, akan tetapi lebih pantas untuk binatang. Sehingga, penulis berita/redaktur ingin meyampaikan pesan bahwa kekejian manusi timbul dengan spontanitas akibat dari pengaruh minuman keras yang bisa berdampak ada pembunuhan dan pemerkosaan.

Pada dasarnya manusia yang melakukan sebuah kriminal akibat dari tidak mendapatkan posisi di tengah-tengah masyarakat. Ia seolah dianggap tidak berguna karena mungkin pengangguran, pendidikan rendah, sehingga dianggap sampah masyarakat. Akibat dari itu semua, seseorang kehilangan eksistensi dan terhina seingga timbul keinginan berbuat kejahatan agar ia merasa dirinya dianggap hadir.

\section{Relasi}

Relasi menurut Fairchlough menjelaskan bagaimana hubungan antara wartawan, khalayak, dan partisipan berita ditampilkan dan digambarkan dalam teks. Hubungan antara wartawan dengan teks yang dituliskan dalam berita di atas merupakan realita sosial kondisi masyarakat saat ini dalam kondisi sulit, apalagi di tengah pendemi Covid-19, mengharuskan masyarakat berpikir dan berusaha keras agar bisa mencari solusi ketika mereka diberhentikan dari pekerjaannya.

Dalam berita ini, wartawan memilki maksud dalam teks berita tersebut pada saat menyajikan bahasa realita saat ini. Sebuah paradigma realita sosial yang terjadi pada masyarakat dewasa ini tentang sebuah kejahatan. Dengan adanya berita ini semakin menambah kasus kriminal berat, khususnya di Kabupaten Serang. Terkait masalah kejahatan sadis/kejam memang bukan hal baru. Adanya himpitan ekonomi semakin membuka peluang manusia untuk melakukan sebuah kejahatan. Selain itu, dengan lemahnya iman membuat seorang yang melakukan sebuah kejahatan seakan tidak merasa takut lagi dengan Tuhannya. Jika sudah demikian ini menjadi tanggung jawab setiap elemen, tak terkecuali pemerintah dan tokoh agama. Kemudian masyarkat sebagai penikmat berita akan memiliki persepsi bahwa pentingnya pembinaan terhadap orang-orang seperti tersangka agar ketika di hidup di tengah-tengah masyarakat dirinya tidak terkesan hina. Psikologis seorang residivis tentunya akan merasa dirinya dijauhi masyarakat dan merasa dirinya tidak bermanfaat. Sehingga pelaku kembali masuk pada lembah atau jurang yang sebenarnya bisa menyengsarakan dirinya sendiri.

\section{Identitas}

Menurut Fairchlough identitas melihat bagaimana identitas wartawan, khalayak, dan partisiapan berita ditampilkan dan digambarkan dalam teks. Melihat latar belakang teks ini, bagaimana wartawan dan masyarakat saling timbal balik, artinya terdapat suatu fenomena ketika wartawan tidak meyajikan berita negatif, maka bagaimana media tersebut dianggap menarik. Maka respon masyarakat sangat penting dalam membaca berita dan mengkritisi agar berita yang disajikan dapat tuntas. Sebuah pemberitaan negatif bagi sebagian masyarkat masih menjadi bacaan yang menarik. Di negara menengah seperti Indonesia, kejahatan yang bermotif permasalahan ekonomi masih banyak ditemukan. Peristiwa yang begitu syarat dengan perbuatan keji seorang pelaku dengan membunuh korban perempuan, seorang pedagang sayur yang tidak berdaya. Korban juga sebagai tulang punggung keluargakarena pendapatan suaminya tidak cukup untuk memenuhi kebutuhan hidup. Ideologi yang terbangun di sini adalah bagaimana media massa dapat mempengaruhi pembaca agar mengutuk perbuatan pelaku dan mengasihi korban.

\section{Aspek Praktik Kewacanaan}

Berita pertama ini, terlihat bahwa wartawan atau media memiliki keberpihakan terhadap korban karena memang menjadi posisi menjadi layak untuk dibela. Bahasa yang disampaika sebenarnya sederhana dalam berita tersebut, akan tetapi terdapat beberapa diksi yang mampu mengundang pembaca untuk terguguah emosinya hanya dengan sajian pemilian kata. Secara tidak langsung wacana yang ada dalam pemberitaan tersebut dapat menjadi representasi kekecewaan keluarga atau masyarakat yang membaca teks tersebut. Pemberitaan ini cukup ramai dibicarakan karena motif pelaku yang terbilang cukup keji serta adanya sebuah ketidakwajaaran yakni setelah 
membunuh, tersangka juga memperkosa jasad korban. Secara prosedur mungkin pelaku bisa saja diperiksa kejiwaannya oleh pihak berwajib. Karena selain di bawah pengaruh minuman keras, pelaku juga dipastikan memiliki riwayat melakukan kejahatan lainnya karena merupakan residivis, akan tetapi dalam teks berita tidak dijelaskan tersangka melakukan kejahatan apa sebelumnya.

Bagi sebagian residivis, penjara tidak membuat ia jera. Bahkan tidak jarang seorang residivis akan melakukan kejahatan yang lebih sadis lagi karena berbagai faktor. Misalnya seorang pencuri sepeda motor, dibui hanya dua sampai tiga tahun, kemudian bebas dan setelah bebas ia melakukan kejahatan lagi dengan merampok toko perhiasan. Dengan fakta yang terjadi, membuktikan bahwa vonis hukum belum tentu membuat jera sesorang, akan tetapi akan semakin membuat merasa biasa saja.

\section{Data 2}

\section{Polres Pandeglang Bongkar Kuburan Korban Miras Oplosan}

PANDEGLANG - Satuan Reserse Kriminal (Satreskrim) Polres Pandeglang melakukan pembongkaran makam warga Kecamatan Labuan yang meninggal setelah menenggak Minuman Keras (Miras) oplosan beberapa waktu lalu. (Paragraf 1...)

Kata Kapolres, kegiatan tersebut bertujuan untuk mengetahui secara jelas penyebab kematian dan cara korban meninggal dunia, karena kematian korban dianggap tidak wajar. (Paragraf 4 ...)

"Hasil pemeriksaan sementara dari keterangan saksi-saksi, korban diduga sebelum meninggal mengkonsumsi obat-obatan... (Paragraf $8 . .$. )

\section{Deskripsi \\ Aspek Tekstual \\ Representasi}

Representasi dalam teks menurut Fairchlough menjelaskan tentang bagaimana peristiwa, orang, kelompok, situasi, keadaan, atau apapun ditampilkan dan digambarkan dalam teks. Pada dasarnya berita ini hadir untuk mencerdasarkan pembaca. Memang kasus semacam ini sudah banyak terjadi di Indonesia. Namun Pandegelang merupakan daerah yang cukup pelosok yang jauh dari kota metropolitan, akan tetapi sudah tren minum-minuman keras oplosan. Ini mengindikasikan bahwa bencana social sudah merajalela hingga ke pelosok deaerah. Kata 'tenggak' menurut KBBI ialah meneguk air langsung dari botol dan sebagainya. Meminum air langsung dari botol walaupun wartawan tidak mengetahui apakah para Koran benar langsung menenggak minumanny dari botol, atau ada media lain seperti gelas atapun plastik. Tujuan penggunaan lema 'meneggak' dianggap lebih dramatis dan lebih mearik dibandingkan dengan kata 'meminum'.

Pada paragraf empat terdapat leksem "dianggap". Memiliki kata dasar 'anggap' yang berarti masih bentuk spekulasi. Duagaan atau hanya menduga-duga, memprediksi kematian yang semula hanya pengaruh minuman namun polisi ingin mengungkap kematian yang sebenarnya pada korban.

Sekali lagi ini merupakan fenomena bencana sosial yang diakaitkan dengan latar belakang ekonomi. Kemiskinan menjadi faktor yang selalu menjadi kambing hitam dan seolah dengan kemiskinan tersebut, seseorang bebas untuk frustrasi dan menyesali kehidupannya. Ada bukti yang pada akhirnya polisi melakukan autopsi karena korban sebelum meninggal juga mengkonsumsi obat-obatan. Namun dalam berita tersebut tidak dijelaskan secara detail bahwa obat-obatan yang dimaksud adalah narkotika. Jika ditelisik, peristiwa ini merupakan fenomena manusia di zaman modern yang menggantungkan keputusasaan pada pelarian yang sebetulnya bisa semakin menyengsarakan hidupnya. Alih-alih permasalahan selesai dengan menenggak minuman keras, korban malah kehilangan nyawanya secara sia-sia.

\section{Relasi}

Relasi menurut Fairchlough menjelaskan bagaimana hubungan antara wartawan, khalayak, dan partisipan berita ditampilkan dan digambarkan dalam teks. Hubungan antara wartawan dengan teks yang dituliskan dalam berita di atas merupakan realita bahwa kondisi sosial masyarkat kita sedang sakit. Bagi seoseorang yang memiliki kejiwaan yang waras maka akan berpikir ulang ketika akan mengkonsumsi minuman keras yang sudah dicampur dengan bahan kimia yang diperoleh relatif mudah, serta kontrol sosial masyarakat yang kurang. Bagi orang-orang yang nekat meminum minuman oplosan merupakan peminum yang sebelumnya biasa meminum keras konvensional tidak terlalu terasa efeknya. Maka dari itu ia berinisiatif mengoplos minuman yang efek mabuknya lebih terasa, dan konyolnya korban tersebut tidak memiliki pengetahuan cara mengoplos minumannya, termasuk kadar kewajaran atau takaaran. Di sini peran masyarakat serta tokoh agama sangat diperlukan untuk mengontrol dan membina korban karena walau bagaimanapun para korban tersebut adalah manusia biasa yang perlu disadarkan. Terkadang masyarakat di sekitar 
serta tokoh agama juga terlalu tidak acuh bahkan hanya bisa mencacinya saja, tanpa dibina atau bahkan dilibatkan di tengah masyarakat. Orang yang demikian sebenarnya butuh pengakuan saja dari masyarkat, dan sekali lagi karena kondisi yang mengakibatkan mereka terjerumus pada lembah kemaksiatan yang pada akhirnya nyawa menjadi taruhannya.

\section{Identitas}

Menurut Fairchlough identitas melihat bagaimana identitas wartawan, khalayak, dan partisiapan berita ditampilkan dan digambarkan dalam teks. Berita ini tersebar luas selain karena kejadian kematian/nyawa yang terkesan murah. Wartawan pada saat medapatkan berita ini juga tidak seutuhnya objektif dan netral. Melihat latar belakang teks ini, bagaimana wartawan dan masyarakat saling timbal balik, artinya terdapat suatu fenomena ketika wartawan tidak meyajikan berita negatif, maka bagaimana media tersebut dianggap menarik. Proses autopsi yang melibatkan 25 polisi termasuk tim forensik ingin membuktikan bahwa penegak hokum serius dalam kasus ini. walaupun terkesan belebihan, menangani satu korban dengan melibatkan banyak personel polisi, dan bukankah semua aktifitas penanganan kasus memaka uang negara. Maka dari itu, penegak hokum kita terkadang juga harus bisa memposisikan kasus sesuai dengan porsinya, apalagi di situasi pandemi seperti sekarang ini yang kita seharusnya menghemat anggaran.

\section{Aspek Praktik Kewacanaan}

Berita kedua ini, terlihat bahwa wartawan atau media memiliki keberpihakan pada polisi. Berbeda dengan berita pertama yang teks bertianya cenderung memuculkan korban, eksistensi korban lebih detail dideskrpsikan. Lain halya dengan berita kedua yang teks berita lebih dominan pada pemberitaan polisi. Padahal pembaca butuh lebih dalam mengenai informasi korban, karena tidak semua pembaca mengetahui berita serupa sebelumnya. Artinya teks berita yag kedua ini kurang detail dan jelas dalam menyamapikan teks berita, terkesan buru-buru, dan kekurangan referensi di lapangan. Bahasa yang disampaika sebenarnya sederhana dalam berita tersebut, akan tetapi terdapat beberapa diksi yang mampu mengundang pembaca untuk terguguah emosinya hanya dengan sajian pemilian kata. Secara tidak langsung wacana yang ada dalam pemberitaan tersebut dapat menjadi representasi kekecewaan keluarga atau masyarakat yang membaca teks tersebut.

Pemberitaan ini cukup ramai dibicarakan karena motif pelaku yang terbilang cukup keji serta adanya sebuah ketidakwajaaran yakni setelah membunuh, tersangka juga memperkosa jasad korban. Secara prosedur mungkin pelaku bisa saja diperiksa kejiwaannya oleh pihak berwajib. Karena selain di bawah pengaruh minuman keras, pelaku juga dipastikan memiliki riwayat melakukan kejahatan lainnya karena merupakan residivis, akan tetapi dalam teks berita tidak dijelaskan tersangka melakukan kejahatan apa sebelumnya.

\section{Data 3}

\section{Oknum ASN Staf Kecamatan Pabuaran Serang Terlibat Mafia Tanah}

Direktorat Reserse Kriminal umum (Ditreskrimum) Polda Banten membongkar sindikat jual beli tanah. Kasus mafia tanah milik warga tersebut melibatkan Aparatur Sipil Negara (ASN) yang bertugas di Kecamatan Pabuaran, Kabupaten Serang. (Paragraf 1...)

Kasus bermula saat tahun 2019 pelaku berinisial HS (49) warga Sukajadi, Curug, Kota Serang menyerahkan blangko akta jual beli tanah lama yang sudah tidak dipergunakan kepada tersangka JJS (46) seorang ASN di Kecamatan Pabuaran, Kabupaten Serang untuk proses administrasi. (Paragraf 3...)

\section{Deskripsi \\ Aspek Tekstual \\ Representasi}

Representasi dalam teks menurut Fairchlough menjelaskan tentang bagaimana peristiwa, orang, kelompok, situasi, keadaan, atau apapun ditampilkan dan digambarkan dalam teks. Pada dasarnya berita ini hadir untuk mencerdasarkan sekaligus meyedarakan pembaca agar lebih hati-hati dalam megurus administrasi. Leksem 'mafia' di sini dipilih oleh redaktur agar nilai teks dianggap lebih menarik disbanding dengan penjahat. Menurut KBBI mafia adalah perkumpulan rahasia yang bergerak di bidang kejahatan (kriminal). Oknum yang bermain di sini adalah ASN di Kecamatan Pabuaran. ASN dimunculkan dalam teks sengaja oleh media bahkan pada judul agar dirasa lebih menarik. ASN memang selalu menjadi sorotan. Sebagai aparatur negara seharusnya ASN memilliki tanggung jawab dan integritas tinggi karena digaji dan fasilitasi oleh negara. Jika oknum ASN malah menjadi mafia ini bertentangan dengan moto ASN itu sendiri. 
Seroang ASN yang semestinya melayani masyarakat, dalam teks ini digambarkan sebagai sosok mafia tanah. Namun yang menjadi pertanyaan mendasar apakah hanya satu orang ASN saja yang terlibat, adakah oknum lainnya yang juga terlibat, ini yang menjadi tugas polisi agar bisa menelisik lebih dalam lagi terkait dengan mafia tanah. Kemudian, apakah korbannya hanya baru ini saja, ataukah sudah banyak korban lantas tidak tercium kasusnya karena ditutup rapat-rapat atau juga korban yang tidak berani lapor kepada pihak berwajib.

\section{Relasi}

Relasi menurut Fairchlough menjelaskan bagaimana hubungan antara wartawan, khalayak, dan partisipan berita ditampilkan dan digambarkan dalam teks. Hubungan antara wartawan dengan teks yang dituliskan dalam berita di atas merupakan realita sosial kondisi masyarakat saat ini. Wartawan ingin menunjukan eksistensi beritanya yang berkaitan dengan berita nasional tentang mafia tanah. Paragraf pertama berita ini ditulis, dijelaskan bahwa kasus ini ditangani oleh polisi tingkat daerah/provinsi yakni Polda. Artinya kasus ini masuk dalam kategori kasus berat. Tinggal bagaimana keseriusan kasus ini bisa diselesaikan dengan baik atau sebaliknya. Wartawan juga seharusnya terus memantau berita ini agar pembaca/masyarakat puas jika hasilnya data diketahui. Kasus ini berhasil ditangani atau gagal ditangani oleh penegak hukum akan menjadi acuan masyarakat ketika melakukan tindakan mengurus adiminstrasi barang berharga, apalagi tanah. Wartawan dalam berita ini sudah semestinya lebih mengutamakan kepentingan masyarakat dalam menyajikan berita. Beritakan sejelas-jelasnya, jangan ada yang ditutup-tutupi sampai masyarkat bisa menilai bahwa di luar sana ada oknum mafia yang sewaktu-waktu mampu memakan korban siapapun dan menyasar siapa saja.

Wacana yang dituliskan dalam berita 3 di atas merupakan realita bahwa mental pegawai pemerintah tidak semua sama. Ada yang pragmatis, mementingkan dirinya sendiri dan kelompok, sehingga membuat oknum yang telah terbiasa dzolim pada masyarakat biasa, akan melakukan kejhatan serupa bahkan levelnya bisa naik lagi. Teks berita ini dapat mencerdasakan masyarakat akan fenomena kejahatan oknum bisa membuat hal administratif akan berjalan macet. Memang tidak menjadi rahasia lagi sejak dulu perkara penyelesaian administrasi di Indonesia kacau dan ini perlu penanganan serius, dan sebenarnya hal ini sudah mulai dibenahi sejak era pemerintahan sekarang. Namun kembali lagi pada mental oknum ASN yang tidak siap menerima perubahan perbaikan, akan terus mencari celah melakukan kejahatan lainnya selama ia masih punya relasi dan kesempatan yang membuat birokrasi di Indionesia berjalan lambat dan selalu menguntungkan oknum dan masyarakat selalu menjadi korban.

\section{Identitas}

Tersangka HS memberikan duit pelicin sebesar Rp20 juta yang dititipkan kepada LJ (61) warga Pabuaran Kabupaten Serang. Duit Rp15 juta masuk kantong JJS, selaku staf kecamatan, dan Rp5 juta mampir ke kantong LJ selaku perantara. (Paragraf $5 . .$. ).

Menurut Fairchlough identitas melihat bagaimana identitas wartawan, khalayak, dan partisiapan berita ditampilkan dan digambarkan dalam teks. Melihat latar belakang teks ini, wartawan ingin menyajikan berita fakta bahwa tersangka oknum ASN tersebut melakukan penipuan secara terstruktur. Selain surat tanah yang berpindah tangan, tersangka juga sudah mengiming-imingi uang kepada tersangka/perantara lainnya. Paragraf lima berita ini mengindikasikan bahwa kejahatan yang terstruktur sebenarnya bisa berhasil dilakukan karena saling mendukung dan berperan dengan baik satu sama lain. Memang setiap kejahatan yang terjadi di sekeliling kita bisa terjadi oleh individu atau kelompok. Menjadi hal rumit pada saat kejahatan yang dilakukan oleh sekelompok orang bisa terjadi pada korban-korban yang tidak berdaya dan tidak mengerti hukum. Sama seperti penjahat lain, mafia tanah seringkali mengincar calon korban yang dilihat memang tidak berdaya. Oknum penjahat juga mungkin akan berpikir dua kali jika calon korbannya adalah orang yang melek hukum. Kebetulan dalam kasus ini korban mafia tanah paham hukum, sehingga langsung melaporkan perkaranya pada pihak berwajib.

Selain itu, sebuah kejahatan yang beritanya naik ke media, terkadang polisi cepat untuk menangani kasusunya, karena masyarakat juga memantau keberlanjutan kasusnya. Kemudian korban terkadang didampingi lembaga bantuan hukum yang membuat tersangka sedikit ketakutan.

\section{Aspek Praktik Kewacanaan}

Berita ketiga ini, terlihat bahwa wartawan atau media memiliki keberpihakan terhadap korban karena memang menjadi posisi teraniaya/terdzolimi oleh seorang mafia atau oknum abdi negara. Pada dasarnya media saat ini berupaya saling berlomba untuk membangun kepercayaan paradigma pada masyarakat. Namun secara umum media selalu menyajikan berita yang justru melemahkan kepercayaan masyarakat terhadap pejabat. Dengan adanya berita seorang ASN di Kecamatan Pabuaran yang menyalahgunakan wewenangnya, tentu saja melanggar norma dia sebagai Aparatur Siapil Negara dan bisa diberikan hukuman yang berat. 
Sifat serakah manusia memang sulit dikendalikan. Tatkala sebuah amanah dinodai oleh hal yang mampu mencoreng nama baik pelaku dan tentu saja merugikan korban karena kasus mafia tanah sedang menjai tranding topic juga di televise nasional yang melibatkan keluarga mantan pejabat di negara ini. Semuanya itu kembali pada kepentigan pribadi dan golongan. Yang menjadi pertanyaan adakah oknum lin yang terlibat dalam kasus mafia tanah tersebut.

Dalam pemberitaan ini wartawan menjadi pihak netral, tidak terlibat sebagai pihak yang mendukung pelaku atau koraban. Keterlibatan wartawan dalam penulisan berita ini dirasa belum selesai karena berita ini menggantung, antara pihak yang salah dan benar menjadi samar di mata pembaca sebagai konsumen berita.

\section{KESIMPULAN}

Berdasarkan hasil analisis wacana kritis terhadap kolo, berita hukum bantennews.co.id edisi Februari 2021 dengan pendekatan dua aspek AWK Norman Fairclough, yakni (1) aspek tekstual berupa telaah pada aspek representasi (frasa, klausa, kalimat, dan subjek kalimat) relasi dan identitas dan (2) telaah praktik kewacanaan yang mengacu pada produksi teks, dapat disimpulkan bahwa headline berita politik, hukum media massa bantennews.co.id edisi Februari 2021 mengandung wacana fenomena sosial yang terjadi dalam kurun waktu februari 2021, khususnya di daerah Banten sendiri yang menjadi objek pemberitaan. Dalam produksi teks tersebut, wanita, dan rakyat/orang lemah selalu menjadi pihak teraniaya, sedangkan pihak yang menjadi superior adalah mereka laki-laki, oknum yang memiliki wewenang menjadi pihak penindas.

Berdasarkan hasil penelitian yang telah dilakukan, dapat penulis rumuskan simpulan sebagai berikut.

1. Analisis representasi, relasi, dan identitas model Fairclough terhadap teks kolom headline berita politik, hukum dan kriminal harian Bantennews.co.id Edisi Februari 2021 adalah sebagai berikut.

a. Representasi dari keseluruhan data yang dianalisis dapat disimpulkan bahwa subjek yang diacu dari seluruh data adalah orang-orang yang menjadi korban pembunuhan, korban minuman keras oplosan, penganiayaan, penipuan, penyalahgunaan wewenang, terutama rakyat kecil yang haknya dirampas oleh penindas. Dalam teks yang dideskripsikan dalam bab IV, penulis mengkritik para tersangka pelaku pembunuhan dan pemerkosaan, para penguasa yang menyalahgunakan jabatannya, serta ketidakberdayaan rakyat kecil untuk melawan orangorang yang berkuasa. Rakyat kecil selalu menjadi korban dari keadaan yang mereka tidak inginkan. Untuk mengungkapkan hal itu, wartawan memilih untuk menampilkan realitas sebagai proses material dan verbal. Proses material akan menampilkan fakta-fakta dari peristiwa yang menjadi bahan pemberitaan, sedangkan proses verbal akan berfungsi sebagai penguat dari peristiwa yang terjadi melalui pendapat-pendapat dari partisipan. Selanjutnya, posisi tema lebih banyak ditempati oleh subjek sebagai fokus pembeitaan, sehingga pembaca akan berpikir sama dengan pikiran wartwan.

b. Relasi dan identitas dari keseluruhan data yang dianalisis dapat disimpulkan bahwa setiap partisipan yang ada pada teks kolom hukum tersebut, dapat digambarkan wartawan bantennews.co.id sebagai pemroduksi berita, pembaca sebagai orang konsumen berita, dan narasumber atau orang yang pendapatnya menjadi bahan rujukan sebagai orang ketiga. Dalam representasinya wartawan menempatkan dirinya sebagai orang yang netral terhadap peristiwa yang terjadi dalam pemberitaan di sekitar Banten. Akan tetapi, pada beberpa bagian wartawan menempatkan dirinya sebagai orang yang pro terhadap pemberitaan, tidak jarang juga wartawan memposisikan diri sebagai pihak kontra. Dalam representasi berikutnya, pihak korban digambarkan sebagai pihak yang mengingingkan adanya suatu perubahan ke arah lebih baik dari sebelumnya.

2. Analisis aspek intertekstualitas model Fairclough terhadap teks kolom headline berita politik, hukum dan kriminal harian bantennews.co.id edisi Februari 2021 sebagai berikut.

Ditinjau dari sumber data yang dianalisis aspek kewacanaan pada kolom headline berita politik, hukum dan kriminal harian bantennews.co.id edisi Februari 2021 diproduksi oleh harian bantennews.co.id yang diwakili oleh penulisnya dari sudut pandang sebagai orang yang sedang mengamati atau memperhatikan kejadian yang pada saat itu terjadi, terutama di sekitar Banten. Penulis memposisikan dirinya sebagai pengamat dari berbagai kejadian yang terjadi di Banten dan sekitarnya. Posisi ini diperlihatkan penulis melalui intertekstualitas yang disajikan dengan kutipan langsung maupun tidak langsung dari berbagai partisipan. Dalam teks ini penulis melihat adanya ketidakbersan dalam peristiwa yang terjadi di Banten dan nasional. Rakyat biasa selalu menjadi korban dari penindasan yang dilakukan oleh penguasa. Dalam memperkuat pendapatnya wartawan mencoba untuk melaporkan atau mengutip suara-suara maupun pendapat dari wartawan anggap penting menyangkut pemberitaan atau pun tulisan yang wartwan kemukakan. Walau pun kita tidak tahu apakah pendapat tersebut datang langsung dari partisipan dan nara sumber atau pendapat tersebut merupakan hasil interpretasi atau formulasi dari wartawan/ penulis. 


\section{Saran}

1. Kolom berita hukum media massa daring bantennews.co.id Edisi Februari 2021, merupakan teks berita terhangat, aktual yang banyak memberitakan dengan gaya pemberitaan yang khas. Oleh karena itu, teks kolom hukum merupakan media yang tepat untuk melatih dalam menggali pemahaman analisa mahasiswa pada tahapan membaca teks nonsastra tingkat perguruan tinggi.

2. Bagi peneliti berikutnya, apabila tertarik menganalisis teks bantennews.co.id dapat meneliti pemberitaan pemberitaan lain yang belum dikaji dalam penelitian ini.

\section{DAFTAR PUSTAKA}

Arikunto, Suharsimi. 2002. Prosedur Penelitian Suatu Pendekatan Praktik (edisi revisi VI). Jakarta:Rineka Cipta

Badara, Kencana Aris. 2012. Analisis Wacana; Teori, Metode, dan, Penerapannya pada Wacana Media. Jakarta:

Burton, Graeme. 2008. Yang Tersembunyi di Balik Media: Pengantar Kepada Kajian media. Yogyakarta: Jalasutra.

Darma, Yoce Aliah. 2009. Analisis Wacana Kritis. Bandung: Yrama Widya. Departemen Pendidikan Nasional, Pusat Bahasa. 2008. Kamus Bahasa Indonesia. Jakarta.

Eriyanto. 2008. Analisis Wacana: Pengantar Analisis Teks Media. Yogyakarta: LKIS.

Fairclough, Norman. 1995. Critical Discourse Analysis: The Critical Study Of Language. Harlow-Essex: Logman Group Ltd.

Fairclough, Norman. 2003. Language and Power: Relasi bahasa, kekuasaan dan ideologi. Malang: Boyan Publishing. Finoza Lamuddin, 2009. Komposisi Bahasa Indonesia. Jakarta: Penerbit Diksi Iksan Mulia.

Hasan, Iqbal. 2002. Metode Penelitian dan Aplikasinya. Jakarta: Ghalia Indonesia.

Hayon, Josep. 2003. Membaca dan Menulis Wacana. Jakarta: Stopia Grafika.

Ibrohim, 2011. "Analisis Wacana Kritis Kolom Catatan Pinggir Majalah Tempo Edisi Februari 2011 dan Rencana Pembelajarannya di SMA" Skripsi Sarjana (Serang: Fakultas Keguruan dan Ilmu Pendidikan Universitas Sultan Ageng Tirtayasa).

Munawaroh, Iroh. 2009. "Analisis Wacana Kritis Teks Dongeng-Dongeng Kabayan dan Rencana Pelaksanaan Pemelajaran (RPP) Membaca Sastra di Kelas XI SMA” Skripsi Sarjana (Serang: Fakultas Keguruan dan Ilmu Pendidikan Universitas Sultan Ageng Tirtayasa).

Moleong, Lexy J. 2007. Metodologi Penelitian Kualitatif. Bandung: Remaja Rosdakarya

Keraf, Gorys. 2004. Komposisi. Semarang: Bina Putera.

Kusuma Okke. 2009. Telaah Wacana. Jakarta: The Intercultural Institute.

Schiffin Deborah. 2007. Ancangan Kajian Wacana. Yogyakarta: Pustaka Pelajar.

Sobur Alex, 2006. Analisis Teks Media. Bandung: Rosda.

Sugiyono. 2007. Metode Penelitian Kuantitatif dan Kualitatif dan R \& D. Bandung: Alvabeta cv.

Tarigan, Henry Guntur. 1993. Pengajaran Wacana. Bandung: Angkasa.

Titscher Stefan dkk. 2009, Metode Analisis Teks \&Wacana. Yogyakarta: Pustaka Pelajar.

Wodak, dkk. 2009. Metode Analisis Teks dan Wacana. Yogyakarta: Pustaka Pelajar. 